\title{
Customer Perceptions of Online Banking Service Quality
}

\author{
Manilall Dhurup \\ Vaal University of Technology, Faculty of Management Sciences, \\ Vanderbijlpark, South Africa \\ Jhalukpreya Surujlal \\ North-West University (Vaal Campus), Faculty of Economic Sciences and Information Technology, \\ Vanderbijlpark, South Africa

\section{Ephraim Redda} \\ Vaal University of Technology, Department of Marketing, \\ Vanderbijlpark, South Africa
}

\section{Doi:10.5901/mjss.2014.v5n2p587}

\section{Abstract}

South Africa has one of the leading banking infrastructures compared to the rest of Africa The South African banking industry currently faces several strategic changes with significant consequences for untapped markets. Among the strategic changes is the provision of online banking services. This study provides an insight of customer perceptions of technology-based banking service quality in a developing country. A structured questionnaire relating to online banking service quality was administered to two hundred Internet banking customers in the Gauteng province of South Africa. One hundred and eighty $(n=180)$ completed questionnaires were received. Using a factor analysis procedure seven factors that influence customer perception of online banking service quality were extracted. These factors were assurance, responsiveness, ease of use, accessibility, fulfilment, speed and accuracy, and contact. The results show that periodic measurements of the levels of online banking service quality should become an integral part of any bank's effort and strategy in improving service quality levels. In this regard an understanding of the dimensionality and relative importance of the service attributes of online banking service quality is of crucial importance to banks.

Keywords: Service quality, e-service quality, online banking, internet banking, customer perceptions, satisfaction, loyalty.

\section{Introduction}

South Africa has one of the leading banking infrastructures compared to the rest of Africa with five major commercial banks namely Standard Bank, Amalgamated Banks of South Africa (ABSA), First National Bank (FNB), Capitec and Nedbank. The banking service market share is highly concentrated as the top banks occupy approximately 98 percent of the sector assets while the remaining 2 percent is attributed to smaller banks (Maumbe, 2006). The South African banking industry currently faces several strategic changes with significant consequences for untapped markets (Maumbe, 2006). With the re-entry of South Africa into the world economy in 1994, the South African banking industry has experienced a number of fundamental forces of change. Globalization, technological advancement, financial innovation, regulation and deregulation are some of the most important forces of change.

During the past decade, the retail banking industry across the world began to face a set of radically new challenges that had an overall negative impact on industry margins and profitability (Loonam \& O'Loughlin, 2008; Haenlein, Kaplan \& Beeser, 2007). For the major part, these challenges were caused by advances in modern information and telecommunication technologies, which ultimately resulted in higher cost transparency and brand switching behaviour. The resultant increase in competitive intensity has led to a commoditisation of basic banking products, such as deposit taking, mortgages and credit extensions. This has further been fuelled by an ever rising number of new entrants in the retail banking sector coming from industries as diverse as insurance and automobile production. From a South African perspective, Fourie, Falkena and Kok (2001) assert that today banks are no longer the only suppliers of banking services - there are many traditional activities of banks that can now be undertaken equally well by markets, 
non-banking financial institutions and non-financial companies.

The competition of providing quality service (be it branch or online banking service) to customers is increasingly becoming tense in today's fast pace changing business environment. Therefore banks need to design appropriate marketing strategy in selling their services to their customers. Providing quality online service to customers becomes even more challenging given today`s sophisticated and demanding customers.

Several terms are often used to describe online technology-driven electronic offering of services. These include internet banking, electronic banking, e-banking or online banking. Electronic banking is a generic term used to describe the process by which a customer may perform banking transactions electronically without visiting a banking institution (Ombati, Mangutu, Nyamwange \& Nyaoa, 2010). The current study adopts Pikkarainen, Pikkarainen, Karjaluoto and Pahnila's (2004) definition of online banking which is described as an internet portal through which customers can use different kinds of banking services, ranging from bill payment to making investments. The various associated transactions include the provision of services such as accessing accounts, transferring funds and buying financial products or services online. For the purposes of this study websites of banks that offer only information on their pages without the possibility of making any transactions were excluded.

\section{Service Quality of Online Banking Services}

Service concepts and strategies have developed in response to the tremendous growth of service industries, resulting in their increased importance in world economies (Zeithaml, Bitner \& Gremler, 2009). Coinciding with the tremendous growth in the global service economy, the demand for individuals who command service marketing expertise is greatly expanding (Hoffman \& Bateson, 2006). In South Africa the services sector (particularly the financial sector) is also becoming increasingly important in the economy. According to a report by Fin24 (2009) the financial services sector's has overtaken the manufacturing sector as the largest contributor to South Africa's GDP. In order to sustain this growth, it is imperative for the financial services sector to seriously focus on the issue of service quality.

The concept of service quality and client care has become one of the key factors contributing to how well or badly a business does in its market (Young, 2005). Ganguli and Roy (2010) define service quality as the overall assessment of service by customers. Customers' perception of service quality is greatly influenced by their service encounters which include, among others, interaction with a bank's personnel, physical facilities and other tangible elements as well as interpersonal and non-human interactions with service providers (Jun \& Cai, 2001). Perceived service quality results from a comparison of customers' prior expectations about a service and their perceptions after the actual experience of the service encounter (Parasuraman, Zeithaml \& Berry, 1985). If expectations are greater than performance, then perceived quality is less than satisfactory and may result in customer dissatisfaction. Al- Hawari and Ward (2006) are of the view that service quality receives much attention in organizations because of its obvious relationship with costs, financial performance, customer satisfaction, and customer retention. A service is normally perceived in a subjective manner. When services are described by customers, words such as 'experience', 'trust', 'feeling' and 'security' are used. These are highly abstract ways of formulating what a service is (Grönroos, 2007). Unlike goods quality, which can be measured with some objectivity, service quality is abstract and elusive. The unique features of services such as inseparability of production and consumption, intangibility, and heterogeneity make measurement of quality a very complex issue. In the absence of objective measures, organizations must rely on consumers' perceptions of service quality to identify their strengths and/or weaknesses, and design appropriate strategies (Karatepe, Yavas \& Babakus, 2005).

Quality, as construct, has traditionally been defined in terms of products but it is not a definitive term. It means different things to different people. Defining quality in the services sector is even more difficult, given that customers often cannot 'see' the service, making the recognition of quality a subjective process and the so-called objective quality does not exist (Du Plessis \& Rousseau, 2007). Due to cultural and environmental effects in general, consumers of services in different countries have different perceptions of what service quality is (Glaveli, Petridou, Liassides \& Spathis, 2006). In service quality literature it is noted that the quality of a product or a service is whatever the customer perceives it to be (Grönroos, 2007).

Quality is often considered to be one of the keys to success. The competitive advantage of an organization is said to depend on the quality, and value, of its goods and services. In service contexts, quality may be the foundation of the competitive edge, but which quality dimension (what or how) is the vital part of excellent total quality? If this question is not answered correctly, then wrong actions may be taken, and the organization would lose its chance to achieve a stronger competitive position (Grönroos, 2007). It is proposed that customer perceptions and preferences of service quality have a significant impact on a bank's success (Al- Hawari \& Ward, 2006). Unfortunately, none of the unique 
features of service can be measured using traditional performance measures since they are based on manufacturing products that are tangible, homogeneous and separable from their production and consumption (Kang \& Bradely, 2001). In retail banking, service quality is a crucial aspect of the customer experience and it is considered a critical measure of organizational performance (Al-Hawari \& Ward, 2006).

Numerous researchers and academics have tried to uncover the general attributes of services that contribute greatly in as far as assessment of service quality is concerned (Young, 2005; Doyle, 2002). In doing so various models have been developed and used in the past in the measurement of service quality. The best-known and most influential studies are those by Zeithaml et al. (2009) related to the development of the SERVQUAL instrument. SERVQUAL is an instrument for measuring how customers perceive the quality of a service. Similarly, Lehtinen and Lehtinen (1991) proposed another model with three dimensions of service quality: physical quality (the quality of the physical products), interactive quality (interaction between customers and the firm's employees) and corporate quality (the corporate image of the firm as perceived by customers). The service quality scale (SERVQUAL) developed by Parasuraman et al. (1985:), which has formed the cornerstone of the measuring of service quality, is one of the more widely used approaches for assessing service quality. The scale comprises 22 items that measure consumers' perceptions and expectations of service quality, using the following dimensions: reliability, responsiveness, assurance, empathy and tangibles.

Santos (2003) defines service quality from an e-service perspective as the consumers' overall evaluation and judgement of excellence and quality of e-service offering in the virtual marketplace. In contrast to their evaluation of traditional service offerings, customers are less likely to evaluate each sub-process in detail during a single visit to a website; rather, they are likely to perceive the service as an overall process and outcome.

Research (Han \& Baek, 2004; Parasuraman, Zeithaml \& Malhotra, 2005) has provided growing evidence of variation in the outcomes of studies on the dimensions of e-service quality that have surfaced in an attempt to address the key attributes of service quality of online services, directly or indirectly. Barnes and Vidgen (2003) developed the Web Quality instrument (WebQual) with 24 items, specifically for online service quality measurement. Seven dimensions were established: reliability, competence, responsiveness, access, credibility, communication and understanding of the individual. The model developed by Parasuraman et al. (2005), referred to as the electronic service quality instrument (ESQ), comprised seven dimensions, namely, efficiency, fulfilment, system availability, privacy, responsiveness, compensation and contact. Various other researchers used modified versions of e-service quality dimensions (Santos, 2003; Yang \& Fang, 2004; Jun \& Cai, 2001) to measure these dimensions in different types of retail settings.

Du Plessis and Rousseau (2007) are of the view that the measurement of service quality has, until recently, received little attention in the marketing literature, primarily because managers often disregarded its importance, and secondly because service quality is so difficult to conceptualise and measure.

\section{Purpose of the Study}

Taking the afore-mentioned into account the study examines customer perceptions of online banking service quality in the South African banking industry.

\section{Research Design}

A quantitative approach was used in addressing the research objective. Du Plessis and Rousseau (2007) view a quantitative approach as systematic and structured, aimed at obtaining information from respondents in a direct, open manner. Results obtained from such an approach are easily quantifiable and has a potentially high degree of accuracy.

\subsection{Sample}

Customers from the Gauteng province in South Africa who made use of online banking facilities from commercial banks constituted the population for the study.

A non-probability sampling method was used to recruit the sample for the study. Since it was difficult to obtain a sample frame for the study, snowball sampling was used to generate an initial sample of online bank customers (Maree, 2011). The initial customers were asked if they knew potential respondents who were online bank customers and these were then contacted by email or telephone to participate in the study.

The sample size for this research was set at 200 online commercial bank customers. This figure is consistent with those in similar studies conducted on online banking services using a non-probability sampling technique (Pikkarainen et 
al., 2004; Santos, 2003; Akinyele \& Olorunleke, 2010; Ombati et al., 2010).

\subsection{Measuring instrument and data collection}

A number of widely used instruments have been developed to measure online service quality. These include E-SQ, ERecS-Qual, Web Qual (Parasuraman et al., 2005; Santos, 2003; Barnes \& Vidgen, 2003) and e-banking portal quality (Bauer, Hammerschmidt \& Falk, 2005). Based on the information collected through the literature study and the instruments, a questionnaire was developed to suit the South African context. The questionnaire contained four sections. In Section A participants were requested to provide demographic information. Section B comprised questions on participants' perceptions of online banking service quality. Section $C$ of the questionnaire focused on customer satisfaction and Section D focused on customer loyalty. Items in Sections B, C and D were scored on a 5-point Likert scale ranging from 1 (strongly disagree) to 5 (strongly agree). This paper reports on customer perceptions of online banking service quality.

The instrument was pre-tested with ten respondents in order to assess the flow of the questions, the time required to complete the questionnaire and to evaluate respondent interest and attention. In addition, a pilot study was conducted to check whether any changes needed to be made to the questionnaire before using it for the main study.

\subsection{Data analysis}

The data were analysed using the Statistical Package for Social Sciences (SPSS 20.0). Descriptive statistics were first used to establish a demographic profile of the respondents. Second, the data was subjected to exploratory factor analysis to identify the factors of online banking service quality as perceived by the participants.

\section{Results}

\subsection{Demographics}

A total of 200 potential respondents were approached to participate in the main survey. Of these, 20 potential respondents refused to participate. This resulted in 180 respondents participating in the main survey. Of the 180 responses used in the study, the survey comprised 58.3 percent males $(n=105)$ and 41.7 percent females $(n=75)$. Most of the respondents, 40.6 percent, were married $(n=73)$, followed by 27.8 percent who were single $(n=50)$. The remaining 16.7 percent were divorced $(n=30)$ and 15 percent were widowed $(n=27)$. The age group $30-39$ years comprised the largest group (36.7\%; $n=66)$, followed by the age group $20-29$ years (25.6\%; $n=46)$, age group $40-49$ years (22.2\%; $n=40)$ and age group $50-59$ years $(13.9 \% ; n=25)$. A small percentage $(1.7 \% ; n=3)$ of those that used internet banking was below the age of 20 years. Approximately 40.6 percent $(n=73)$ of the respondents indicated that they accessed the internet through their employers' network and 33.3 percent $(n=60)$ accessed it at home through fixed line or wireless broadband. Approximately 24.4 percent $(n=44)$ of the respondents still used dial-up access from their homes.

\subsection{Exploratory Factor Analysis (EFA)}

Principal components analysis using Varimax rotation was applied to the data set. The appropriateness of factorability on the data set was first established. This was done by conducting the Bartlett's Test of Sphericity and the Kaiser-MeyerOlkin (KMO) measure of sampling adequacy (MSA). Both these tests (KMO $=0.89$; Bartlett's Test of Sphericity $(s i g=0.00)$ were found to be acceptable to conduct factor analysis. In addition, a minimum eigenvalue of 1 was used to extract the factors. An examination of the rotated component matrix revealed that 7 items did not load cleanly on a single factor because they had low factor loadings, low inter-item correlation and multiple or unstable loadings (Aldalaigan \& Buttle, 2002). These items were subsequently removed to reduce ambiguity in the interpretation of the factors (Tabachnick \& Fidell, 2001) and a second PCA was performed on the remaining items. The second PCA extracted 7 factors which accounted for $69.92 \%$ of the overall variance in the scale item scores with two to twelve loadings on each factor. These factors were labelled as follows: assurance, trust and appeal, responsiveness, ease of use, accessibility, fulfilment, speed and accuracy, and contact.

The rotated factor matrix is presented in Table 1 
Table 1: Rotated factor matrix

\begin{tabular}{|c|c|c|c|c|c|c|c|}
\hline \multirow{2}{*}{ Factor and variable descriptions } & \multicolumn{7}{|c|}{ Factors } \\
\hline & 1 & 2 & 3 & 4 & 5 & 6 & 7 \\
\hline \multicolumn{8}{|l|}{ Assurance, trust and appeal (Factor 1) } \\
\hline My bank does not misuse my personal information & .585 & .340 & .121 & -.138 & .303 & .076 & -.005 \\
\hline I believe there is no way people can access my personal account & .692 & .280 & .023 & .213 & .071 & .187 & -.005 \\
\hline I feel safe in my transactions with my bank & .777 & .213 & .134 & .068 & .215 & .098 & -.052 \\
\hline My bank protects my personal information & .842 & .206 & .184 & .027 & .135 & .084 & -.095 \\
\hline My bank's security system for Internet banking seems rigorous & .788 & .180 & .179 & .042 & .148 & .052 & .042 \\
\hline Overall, my bank's website seems security-conscious & .802 & .140 & .119 & .094 & .152 & .031 & .074 \\
\hline My bank does not share my personal information with other sites & .829 & .100 & .058 & .109 & -.017 & .087 & .119 \\
\hline My bank's name is well known & .783 & -.038 & .072 & .087 & .141 & .104 & .156 \\
\hline My bank has a good reputation & .830 & .007 & .061 & .122 & .125 & -.062 & .169 \\
\hline I have confidence in my bank's service & .775 & .029 & .096 & .097 & .153 & .028 & .203 \\
\hline My bank's website is aesthetically appealing & .736 & .076 & .225 & .078 & .083 & .150 & .073 \\
\hline My bank's web design is visually appealing & .628 & .309 & .126 & .080 & .074 & .012 & .074 \\
\hline \multicolumn{8}{|l|}{ Responsiveness (Factor 2) } \\
\hline My bank's website is interesting to visit & .208 & .688 & -.071 & .048 & .106 & .171 & .155 \\
\hline My bank provides prompt responses to my requests by e-mail or other means & .297 & .700 & .046 & -.054 & .115 & .244 & .121 \\
\hline My bank promptly resolves problems I encounter with my online transactions & .192 & .680 & .260 & -.034 & .168 & .113 & .099 \\
\hline My bank repairs a breakdown on the website quickly & .142 & .698 & 217 & .243 & -.073 & .075 & .092 \\
\hline \multicolumn{8}{|l|}{ Ease of use (Factor 3) } \\
\hline It is easy to find what I need on my bank's website & .242 & .265 & .798 & .082 & .024 & .108 & .024 \\
\hline My bank's website does not require a lot of effort to use & .226 & .134 & .816 & .042 & .217 & .172 & -.076 \\
\hline The organisation and structure of the online content is easy to follow & .204 & .037 & .759 & .104 & .132 & -.009 & .127 \\
\hline \multicolumn{8}{|l|}{ Accessibility (Factor 4) } \\
\hline The service delivered through my bank's website is quick & .162 & .129 & -.106 & .636 & .469 & -.071 & .149 \\
\hline My bank's website loads fast all the time & .030 & .054 & .170 & .838 & .114 & .089 & .084 \\
\hline My bank's website does not freeze during a transaction & .178 & .085 & .120 & .830 & .047 & .011 & .117 \\
\hline My bank is easily accessible by telephone & .177 & .283 & .036 & .229 & .119 & .107 & .805 \\
\hline \multicolumn{8}{|l|}{ Fulfillment (Factor 5) } \\
\hline It is easy to use my bank's website & .210 & -.103 & .454 & .018 & .547 & .074 & .290 \\
\hline The functionality delivered through my bank's website addresses my banking needs & .253 & .040 & .271 & .203 & .709 & .016 & .156 \\
\hline When my bank promises to do something by a certain time, it does so & .202 & .302 & .198 & .210 & .615 & .153 & .118 \\
\hline My online transactions with the bank are always accurate & .307 & .160 & .014 & .265 & .725 & .081 & -.071 \\
\hline \multicolumn{8}{|l|}{ Speed and accuracy (Factor 6) } \\
\hline I am able to get on the bank's site quickly & .092 & .213 & .136 & -.014 & .029 & .857 & .143 \\
\hline It is quick to complete a transaction through my bank's website & .156 & .092 & .311 & .257 & .031 & .731 & -.080 \\
\hline My bank's website makes accurate promises about the services being delivered & .114 & .223 & -.102 & .007 & .141 & .762 & .186 \\
\hline \multicolumn{8}{|l|}{ Contact (Factor 7) } \\
\hline My bank's site has customer service representatives available online & .212 & .211 & .101 & .215 & .149 & .189 & .781 \\
\hline My bank's website offers the ability to speak to a person if there is a problem & .177 & .283 & .036 & .229 & .119 & .107 & .805 \\
\hline Eigenvalue & 11.52 & 2.90 & 2.38 & 1.94 & 1.32 & 1.19 & 1.10 \\
\hline$\%$ of Variance & 36.01 & 9.06 & 7.44 & 6.08 & 4.12 & 3.74 & 3.44 \\
\hline Cumulative $\%$ & 36.01 & 45.07 & 52.52 & 58.61 & 62.73 & 66.48 & 69.92 \\
\hline Reliability (Cronbach alpha) & 0.949 & 0.780 & 0.846 & 0.805 & 0.795 & 0.789 & 0.851 \\
\hline Means & 4.32 & 4.31 & 4.28 & 4.27 & 4.24 & 4.07 & 4.07 \\
\hline
\end{tabular}

Item reliability for each extracted factor was evaluated using Cronbach alpha (a). The factors' internal consistency ranged from $0.780-0.949$, which were close to or greater than the recommended significance level of 0.70 (Nunnally \& Bernstein, 1994) indicating an acceptable level of reliability. 


\section{Discussion}

Han and Baek (2004) and Parasuraman et al. (2005) highlight the fact that there is growing evidence of the variation in the outcomes of various studies that have attempted to address the key attributes of electronic services. The current study attempted to add to the body of knowledge on service quality by identifying factors which online banking customers perceive as important.

Factor one, labelled assurance, trust and appeal, comprised 12 variables and accounted for $36.01 \%$ of the variance. This factor refers to the degree to which customers find transacting online safe, and reliable and the appearance of the bank's website physically and aesthetically appealing. The items that loaded onto this factor relate mainly to assurance, security, privacy and trust issues involved when transacting online banking. Aspects regarding the aesthetic and visual appeal of the web page also loaded onto this factor. The finding of these aspects on online services is consistent with previous studies (Zeithaml et al., 2009; Bauer et al., 2005; Loonam \& O'Loughlin, 2008). This factor highlights that online banking customers are concerned mainly about the safety of using internet banking for conducting transactions. It provides a strong indication that customers want to be assured that the bank can be trusted with their personal information when conducting transactions.

The second factor, labelled responsiveness, comprised four variables and accounted for 9.06 percent of the variance. This factor relates to the effective handling of queries and problems whenever customers need the bank's assistance. The items that loaded onto this factor related to the promptness of the bank's response regarding customer requests and resolving problems encountered when customers conduct their online transactions. This factor is consistent with the 'responsiveness' dimension identified in an online setting in previous studies (Zeithaml et al., 2009; Loiacono, Watson \& Hoodhue, 2000; Parasuraman et al., 2005; Loonam \& O'Loughlin, 2008; Hu \& Liao, 2011). Although the human contact is absent in an online setting, customers still desire responsive action from banks as and when they experience problems, and want problems be solved urgently. By responding swiftly to customers, banks may be able to encourage higher adoption rates of online banking.

The third factor was labelled ease of use. Four variables that accounted for 7.45 percent of the variance loaded onto this factor. This factor refers to the ease of accessing and using the bank's website for searching, navigating and transacting. The items that loaded onto this factor related to ease of use of the website, the organization and structure of online content that makes the website easy to follow with less effort. One of the main reasons why consumers use internet banking is that it is convenient and easy (Zeithaml et al., 2009; Santos, 2003; Ombati et al., 2010; Hamadi, 2010; Yoon, 2010). Therefore the learnability and understandability of user interfaces need to be considered by bankers so that customers are able to use online banking effectively, efficiently and to their satisfaction.

The fourth factor, comprising 4 variables, was labelled accessibility and accounted for 6.08 percent of the variance. This factor refers to the availability and loading of a bank's website for performing transactions at any time. The items that loaded onto this factor related to the loading and accessibility of the website for transactions. This factor is consistent with previous literature regarding accessibility in online banking (Zeithaml et al., 2009; Loonam \& O'Loughlin, 2008). For customers accessibility is an important factor since it is quicker, offers convenience, and provides a variety of transactions which can be conducted at any time

The fifth factor, comprising 4 variables which accounted for 4.12 percent of the variance, was labelled fulfilment. This factor refers to the extent to which the bank's website promises about the functionality of online services are fulfilled. The items that loaded onto this factor related to the functionality of the website, fulfilment of promises by the bank and accuracy of transactions conducted. Customers evaluate websites according to the extent to which the site's promises about delivery and item availability are fulfilled (Parasuraman et al., 2005). Internet banking customers would also like the website to have all the functionality needed so that transactions can be effectively and efficiently conducted.

The sixth factor was labelled speed and accuracy. Three items which accounted for 3.74 percent of the variance loaded onto this factor. This factor refers to aspects such as how quickly and accurately customers can perform their banking transactions through the bank's website. In line with previous studies, it was found that customers have an expectation that 'internet banking is quick to conduct' and they also want their transaction to be 'accurate' as promised (Ombati et al., 2010, Akinyele \& Olorunleke, 2010).

The seventh factor was labelled contact. Only two items which accounted for 3.44 percent of the variance loaded onto this factor. This factor refers to whether the bank can be reached by a different medium of communication to help customers when they experience problems. An analysis of the literature revealed that internet banking customers would like to reach and communicate with a person in instances where they encounter a serious problem or security risk regarding their online transactions (Parasuraman et al., 2005; Hu \& Liao, 2011). The ability to be in contact with and 
communicate with someone with regard to online banking issues potentially increases the confidence one may have in online banking.

\section{Limitations and Implications for Future Research}

While the sampling technique and sample size are consistent with similar studies conducted on online banking services, the study was conducted over one geographic location in South Africa. Given the fact that South Africa consists of different sub-markets, each with distinct characteristics, caution should be exercised when generalising the results of this study over the entire population.

The findings of the current study have implications for future research. Future research could contribute to analysing consumer behaviour by adding other perception variables that may influence online banking service quality. A quantitative research design was employed in this research. Future research one may consider a mixed method approach, employing both qualitative and quantitative methods. The study was not organization/bank-specific. For more practical purposes, future endeavours could be focused in organization/bank-specific studies. It must be emphasised that more research is needed before any final conclusions on the dimensionality and validity of online banking service quality is reached.

\section{Conclusion}

The financial services industry is changing rapidly. Technology, government regulation and deregulation, and increasing customer sophistication are forcing financial service institutions to re-evaluate their current business practices in light of a changing and competitive business environment. Banks are forced to develop and use alternative service channels with the aim of building bigger market share, improving customers' perceptions of service quality and achieving customer loyalty. The absence of interpersonal contact and the replacement of human-to-human interaction with human-tomachine interaction have serious implications for dimensions to be used when evaluating e-service quality for purposes of customer satisfaction and loyalty. Thus, an understanding of the dimensionality and relative importance of the service attributes of online banking service quality is of crucial importance to banks.

\section{References}

Akinyele, S.T. \& Olorunleke, K. (2010). Technology and service quality in the banking industry: An empirical study of various factors in electronic banking services. International Business Management, 4, 209-221.

Aldalaigan, A.H. \& Buttle, F.A. (2002). SYSTRA-SQ: A new measure of bank service quality. Industrial Journal of Service Industry Management, 13(3), 362-381.

Al-Hawari, M. \& Ward, T. (2006). The effect of automated service quality on Australian banks' financial performance and the mediating role of customer satisfaction. Marketing Intelligence \& Planning, 24(2), 127-147.

Barnes, S.J. \& Vidgen, R. (2002). An Integrative Approach to the Assessment of E-Commerce Quality. Journal of Electronic Commerce Research, 3(3), 114-27.

Barth, M.N., Godemann, J., Rieckmann, M. \& Stoltenberg, U. (2007): Developing key competencies for sustainable development in higher education. Internal Journal of Sustainability in Higher Education, 8(4), 416-430.

Bauer, H., Hammerschmidt, M \& Falk, T. (2005). Measuring the quality of E-banking portals. International Journal of Bank Marketing, 23(2), 153-175.

Doyle, P. (2002). Marketing Management and Strategy. London: Pearson Education Limited.

Du Plessis, F. \& Rousseau, G.G. (2007). Buyer Behaviour: Understanding Consumer Psychology and Marketing. Cape Town: Oxford University Press Southern Africa.

Fin24. (2009). Financial services biggest contributor to GDP. Available at: http://www.tradeinvestsa.co.za/news/356040.htm Date accessed: 10/06/ 2010.

Fourie, L.J., Falkena, H.B. \& Kok, W.J. (2001). Student Guide to the South African Financial System. Cape Town: Oxford University Press, Southern Africa.

Ganguli, S. \& Roy, S.K. (2010). Generic terminology-based service quality dimensions in banking: impact on customer satisfaction and loyalty, International Journal of Bank Marketing, 29(2), 276-291.

Glaveli, N.G., Petridou, E., Liassides, C. \& Spathis, C. (2006). Bank service quality: Evidence from five Balkan countries. Managing Service Quality, 16(4), 380-394.

Grönroos, C. (2007). Service Management and Marketing: Customer Management in Service Competition. England: John Wiley \& Sons Ltd.

Haenlein, A., Kaplan, A.M. \& Beeser, A.J. (2007). A model to determine customer lifetime value in a retail banking context. European 
Management Journal, 25(3), 221-234.

Hamadi, C. (2010). The impact of quality of online banking on consumer commitment. Communications of the IBIMA 2. Available at: http://www.ibimapublishing.com/journals/CIBIMA/cibima.html. Accessed on 2011/03/07.

Han, S. \& Baek, S. (2004). Antecedents and consequences of service quality in online banking: an application of the SERVQUAL instrument. Advances in Consumer Research, 31, 208-214.

Hoffman, K.D. \& Bateson, J.E.G. (2006). Service Marketing: concepts, strategies \& cases. New York: Thompson South Western.

$\mathrm{Hu}, \mathrm{Y} \&$ Liao, P. (2011). Finding critical criteria of evaluating electronic service quality of Internet banking using fuzzy multiple-criteria decision making. Applied Soft Computing, 11, 3764-3770.

Jun, M. \& Cai, S. (2001). The key determinants of internet banking service quality: a content analysis, International Journal of Bank Marketing, 19(7), 276-291.

Kang, H. \& Bradely, G. (2001). Measuring the performance of IT services: An assessment of SERVQUAL. International Journal of Accounting Information Systems, 3, 151-164.

Karatepe, O.M., Yavas, U. \& Babakus, E. (2005). Measuring service quality of banks: Scale development and validation. Journal of Retailing and Consumer Services, 12, 373-383.

Lehtinen, U. \& Lehtinen, J.R. (1991). Two approaches to service quality dimensions. The Service Industries Journal, 11(3), $287-303$.

Loiacono, E.T., Watson, R.T. \& Hoodhue, D.L. (2002). WEBQUAL: Measure of web site quality. Marketing Educators Conference: Marketing Theory and Applications, 13, 432-437.

Loonam, M. \& O'Loughlin, D. (2008). Exploring e-service quality: A study of Irish online banking. Marketing Intelligence \& Planning, 26(7), 759-780.

Maree, K. (2011). First Steps in Research (5th ed.). Pretoria: Van Schaik Publishers.

Maumbe, M.B. (2006). Digital Financial Service Delivery to Poor Communities in South Africa: A Preliminary Assessment. International Review of Business Research Papers, 2(2), 72-79.

Nunnally, J. C. \& Bernstein, I. H. (1994). Psychometric Theory (3rd ed.). New York: McGraw-Hill.

Ombati, T.O., Mangatu, P.O., Nyamwange, S.O. \& Nyaoa, R.B. (2010). Technology and service quality in the banking industry. African Journal of Business and Management (AJBUMA), 1, 151-164.

Parasuraman, A., Zeithaml, V.A. \& Berry, L.L. (1985). A conceptual model of service quality and its implications for future research. Journal of Marketing, 49, 41-45.

Parasuraman, A., Zeithaml, V. \& Malhotra, A. (2005). E-S-QUAL: A multiple-item scale for assessing electronic service quality. Journal of Service Research, 7(3), 213-233.

Pikkarainen, T., Pikkarainen, K., Karjaluoto, H. \& Pahnila, S. (2004). Consumer acceptance of online banking: an extension of technology acceptance model. Internet Research, 14(3), 224-235.

Santos, F. (2003). E-service quality: A model of virtual service quality dimensions. Managing Service Quality, 13(3), 233-246.

Tabachnick, B.G., \& Fidell, L.S. (1996). Using Multivariate Statistics (3rd ed.). New York: Harper Collins College Publishers.

Yang, Z. \& Fang, X. (2004). Online service quality dimensions and their relationships satisfaction; a content analysis of customer reviews of securities brokerage services. International Journal of Service Industry Management, 15(3), 302- 325.

Yoon, C. (2010). Antecedents of customer satisfaction with online banking in China: The effects of experience. Computers in Human Behavior, 26, 1296-1304.

Young, L. (2005). Marketing, The Professional Services Firm. New York: John Wiley \& Sons Inc.

Zeithaml, V.A, Bitner, M.J. \& Gremler, D.D. (2009). Service Marketing: Integrating Customer Focus Across the Firm. Boston: McGrawHill/Irwin. 